\title{
Gaya Kepemimpinan Demokratik Terhadap Loyalitas Karyawan Melalui Motivasi Ekstrinsik Sebagai Variabel Intervening
}

\author{
Vinny Hafisah ${ }^{1}$, Mahendra Fakhri ${ }^{2}$ \\ Universitas Telkom \\ 'hafisahvinny@gmail.com \\ ${ }^{2}$ mahendrafakhri@telkomuniversity.ac.id
}

\begin{abstract}
ABSTRAK
PT Propan Raya ICC Bandung merupakan perusahaan produksi yang beroperasi di sektor chemichal coating. PT Propan Raya ICC Bandung menyadari pentingnya manajemen sumber daya manusia untuk menjaga loyalitas karyawan sehingga dapat mendukung keberhasilan pencapaian tujuan perusahaan. Penelitian ini memiliki tujuan, pertama mengetahui pengaruh gaya kepemimpinan demokratik terhadap motivasi ektrinsik. Kedua mengetahui pengaruh gaya kepemimpinan demokratik terhadap loyalitas karyawan. Ketiga mengetahui pengaruh gaya kepemimpinan demokratik terhadap loyalitas karyawan melalui motivasi ekstrinsik sebagai variabel intervening. Penelitian ini menggunakan pendekatan kuantitatif dengan jenis penelitian deskriptif dan kausalitas. Pengambilan sampel menggunakan teknik sampling jenuh dengan sampel sebanyak 42 responden. Metode analisis yang digunakan analisis jalur. Hasil menunjukan bahwa gaya kepemimpinan demokratik, motivasi ekstrinsik dan loyalitas karyawan berada pada kategori baik. Hasil analisis jalur menunjukan bahwa gaya kepemimpinan demokratik berpengaruh terhadap motivasi ekstrinsik sebesar 0,872. Gaya kepemimpinan demokratik berpengaruh terhadap loyalitas karyawan sebesar 0,660. Gaya kepemimpinan demokratik berpengaruh terhadap loyalitas karyawan melalui motivasi ekstrinsik sebagai variabel intervening sebesar 0,267. Kesimpulan penelitian ini bahwa pengaruh gaya kepempinanan demokratik berpengaruh langsung terhadap loyalitas karyawan lebih besar dibandingkan pengaruh gaya kepemimpinan demokratik terhadap loyalitas karyawan melalui motivasi ekstrinsik dengan nilai variabel residu sebesar 0,342 , artinya terdapat $34,2 \%$ faktor lain diluar penelitian yang mempengaruhi variabel dependen.
\end{abstract}

Kata Kunci : Kepemimpinan Demokratik, Loyalitas Karyawan, Motivasi Ekstrinsik.

\begin{abstract}
PT Propan Raya ICC Bandung is a production company that operates in the sectors of chemicals in coating. PT Propan Raya ICC Bandung realize the importance of human resource management to maintain the loyalty of employees so as to support the successful achievement of corporate goals. This research has a purpose, first determine the effect of the democratic leadership style to extrinsic motivation. Both determine the effect of the democratic leadership style on employee loyalty. Third determine the effect of the democratic leadership style on employee loyalty through extrinsic motivation as an intervening variable. This study uses a quantitative approach with descriptive research and causality. Sampling using saturation sampling with a sample of 42 respondents. The analytical method used path analysis. Results showed that the democratic leadership style, extrinsic motivation and loyalty of employees are in either category. The results of path analysis showed that the democratic leadership style affects the extrinsic motivation of 0.872. Democratic leadership style influence on employee loyalty at 0.660. Democratic leadership style influence on employee loyalty through extrinsic motivation as an intervening variable of 0.267. The conclusion of this study that the influence of the force of the democratic kepempinanan direct effect on employee loyalty is greater than the influence of the democratic leadership style on employee loyalty through extrinsic motivation with variable residual value of 0.342 , meaning that $34.2 \%$ are other factors beyond the research that affect the dependent variable.
\end{abstract}


Keywords: Democratic Leadership, Employee Loyalty, Extrinsic Motivation.

Naskah diterima: 26 Juli 2019, direvisi: 15 Agustus 2019, diterbitkan: 16 September 2019

\section{PENDAHULUAN}

Manusia memiliki peran penting di dalam perusahan. Salah satu peran pentingnya yaitu sebagai pelaku, pemikir dan perencana. Oleh karena itu sumber daya manusia dianggap menjadi asset penting yang perlu diperhatikan untuk dijaga kelangsungannya selama bekerja di perusahaan, sehingga asset perusahaan dapat memberikan kemampuan terbaiknya dan bekerja dengan semangat serta memiliki loyalitas tinggi kepada perusahaan (Afani, 2013). Menurut Soegandhi et al (2013) loyalitas atau kesetiaan yang merupakan salah satu unsur yang digunakan dalam penilaian karyawan dengan mencakup kesetiaan terhadap pekerjaanya, jabatan dan organisasi. Kesetian ini dicerminkan dengan kesediaan karyawan menjaga dalam membela organisasi didalam maupun diluar pekerjaan dari rongrongan orang yang tidak bertanggung jawab. Kesetiaan ditunjukkan dengan adanya kemauan untuk tetap bekerja di perusahaan. Berdasarkan data proporsi jumlah karyawan tetap dan kontrak di PT Propan Raya ICC pada tahun 2015 karyawan tetap sebesar 44\%, karyawan kontrak 56\%, lalu tahun 2016 karyawan tetap sebesar $35,71 \%$, karyawan kontrak 64,29\% dan pada tahun 2017 persentase karyawan tetap semakin menurun sebesar 30,71\%, karyawan kontrak sebesar $69,29 \%$. Dapat disimpulkan bahwa proporsi jumlah karyawan tetap lebih sedikit daripada jumlah karyawan kontrak. Menurut Manager HRD PT Propan Raya proporsi karyawan saat ini salah satunya dipengaruhi oleh kondisi perusahaan yang sedang berkembang baik secara bisnis maupun struktur organisasi, pengembangan struktur organisasi membutuhkan karyawan baru yang harus melalui tahap kontrak. Ditambah saat ini perusahaan sangat selektif dalam mengangkat karyawan tetap. Sehingga keberadaan karyawan tetap penting bagi keberlangsungan perusahaan terutama bagi PT Propan Raya yang sedang berkembang. Menurut Marfuah dan Ruzikna (2015) mengatakan bahwa perusahaan akan sulit berkembang jika tidak memiliki karyawan yang memiliki loyalitas yang tinggi. Sedangkan dapat dibandingkan dengan proporsi persentase pertumbuhan jumlah karyawan tetap yang semakin menurun dapat diartikan bahwa karyawan yang loyal di perusahaan ini hanya sedikit. Selain itu loyalitas dipengaruhi oleh gaya kepemimpinan, Menurut Welyanto dan Halim (2017) salah satu faktor yang terpenting dalam membentuk loyalitas karyawan adalah gaya kepemimpinan dari seseorang yang memimpin. Berdasarkan hasil pra survey gaya kepemimpinan dapat disimpulkan bahwa gaya kepemimpinan yang digunakan pemimpin di PT Propan Raya ICC adalah gaya kepemimpinan demokratik. Selain gaya kepemimpinan, ternyata menurut Anasrulloh dan Agatha (2018) mengatakan bahwa loyalitas karyawan dapat dipengaruhi motivasi kerja. Karena motivasi dapat mengarahkan dan mendorong karyawan untuk melakukan pekerjaan sesuai dengan harapan perusahaan. Menurut Frianto dan Putra (2013) motivasi ekstrinsik merupakan dorongan motivasi dapat bersumber dari luar diri karyawan dikarenakan adanya ajakan, suruhan, atau paksaan dari orang lain sehingga seseorang mau melakukan 
sesuatu tindakan. Berdasarkan hasil pra survey menunjukan bahwa motivasi ektrinsik karyawan PT Propan Raya ICC secara keseluruhan belum sesuai dengan yang diharapkan. Dengan adanya motivasi, secara tidak langsung karyawan akan merasa diperhatikan sehingga karyawan semakin loyal dan tetap berkomitmen untuk tetap tinggal diperusahaan tanpa paksaan. Berdasarkan fenomena di atas, penulis melihat adanya peluang riset untuk meneliti kondisi eksternal pada PT Propan Raya ICC Bandung di mana salah satunya adalah gaya kepemimpinan demokratik dan motivasi ekstrinsik. Sehingga, penulis tertarik untuk menjadikan variabel ini sebagai variabel independen dalam penelitian ini. Oleh karena itu, penulis membuat penelitian ini untuk mengetahui sejauh mana variabel di atas berpengaruh terhadap loyalitas karyawan melalui penyebaran kuisioner terhadap para karyawan tetap.

\section{KAJIAN LITERATUR \\ Manajemen Sumber Daya Manusia}

Menurut Sunyoto (2014: 1) sumber daya manusia sebagai suatu faktor yang penting dalam suatu organisasi atau perusahaan, disamping faktor lain seperti aktiva dan modal. Oleh karena itu sumber daya manusia harus selalu dikelola dengan baik untuk meningkatkan efektivitas dan efisiensi organisasi, sebagai salah satu fungsi dalam perusahaan yang dikenal dalam perusahaan yang dikenal dengan manajemen sumber daya manusia.

\section{Gaya Kepemimpinan}

Menurut Thoha (2013: 49) bahwa gaya kepemimpinan merupakan norma perilaku yang digunakan oleh pemimpin pada saat mempengaruhi perilaku orang lain seperti yang dilihat. Gaya Kepemimpinan terbagi menjadi dua kategori gaya yang ekstrem yaitu:

1. Gaya Kepemimpinan Otokratis, gaya ini dapat dipandang sebagai gaya yang didasarkan atas kekuatan posisi dan penggunaan otoritas.

2. Gaya Kepemimpinan Demokratis, gaya ini dapat dikaitkan dengan kekuatan personal dan keikutsertaan para pengikut dalam proses pemecahan masalah dan pengambilan keputusan.

\section{Kepemimpinan Demokratik}

Menurut Siagian (dalam Marfuah \& Ruzikna, 2015: 7) gaya kepemimpinan demokratik adalah seorang pemimpin yang demokratik dihormati dan disegani dan bukan ditakuti karena perilakunya dalam kehidupan organisasional. Adapun dimensi gaya kepemimpinan demokratis menurut Pasolong (dalam herdianti 2017: 14) diantaranya adalah:

1. Keputusan dibuat bersama

Pemimpin yang demokratis tidak sungkan untuk terlibat bersama-sama dengan bawahan untuk membuat keputusan serta melakukan aktivitas kerja demi pencapaian tujuan organisasi.

2. Menghargai potensi setiap bawahannya

Kepemimpinan demokratis menghargai setiap potensi individu dan bersedia mengakui keahlian para spesialis dengan bidangnya masing-masing, mampu memanfaatkan kapasitas setiap anggota seefektif mungkin pada saat dan kondisi yang tepat.

3. Mendengar kritik, saran/pendapat dari bawahan

Mendapat kritikan, saran/pendapat dari bawahan merupakan hal yang wajar dalam kehidupan organisasi. Dengan demikian akan ada kecenderungan untuk lebih meningkatkan potensi diri dan bisa menjadi lebih baik dari sebelumnya serta belajar dari kesalahan yang telah dilakukan.

4. Melakukan kerjasama dengan bawahannya. Pemimpin yang baik adalah pemimpin yang mampu bekerja sama/ terlibat langsung secara bersama-sama dalam menjalankan tugas demi pencapaian tujuan organisasi. Pemimpin juga tidak sungkan untuk terjun langsung kelapangan untuk menjalankan tugas.

\section{Motivasi}

Menurut Ernest (dalam Mangkunegara, 2015: 94) Motivasi kerja didefinisikan sebagai kondisi yang berpengaruh dalam membangkitkan, mengarahkan, dan memelihara perilaku yang berhubungan dengan lingkungan kerja. Menurut Suwatno dan Priansa (2016: 179) teori motivasi yang 
sudah lazim dipakai untuk menjelaskan sumber motivasi sedikitnya bisa digolongkan menjadi dua, yaitu :

a. Motivasi Instrinsik

Motivasi instrinsik adalah motif-motif yang menjadi aktif atau berfungsinya tidak perlu dirangsang dari luar, karena dalam diri setiap individu selalu ada dorongan untuk melakukan sesuatu. Faktor individu yang biasa mendorong seseorang melakukan sesuatu adalah:

1) Minat, sesorang akan terasa terdorong untuk melakukan sesuatu kegiatan tersebut merupakan kegiatan yang sesuai dengan minatnya.

2) Sikap Positif, seseorang yang mempunyai sikap positif terhadap suatu kegiatan dengan rela ikut dalam kegiatan tersebut, dan akan berusaha sebisa mungkin menyelesaikan kegiatan yang bersangkutan dengan sebaik-baiknya.

3) Kebutuhan, setiap orang yang mempunyai kebutuhan tertentu dan akan berusaha melakukan kegiatan apapun asal kegiatan tersebut bisa memenuhi kebutuhannya. Jenis motivasi ini timbul dari dalam diri individu sendiri tanpa ada paksaan atau dorongan dari orang lain, tetapi atas dasar kemauan diri sendiri. Motivasi pada dasarnya memang ada dalam diri setiap orang, seperti kata asal motivasi yaitu motif yang berarti daya penggerak untuk melakukan sesuatu.

b. Motivasi Ekstrinsik

Motif ekstrinsik adalah motif-motif yang aktif dan berfungsinya karena adanya perangsang dari luar. Motivasi ekstrinsik dapat juga dikatakan sebagai bentuk motivasi yang didalamnya aktivitas dimulai dan diteruskan berdasarkan dorongan dari luar yang tidak berkaitan dengan dirinya. Ada dua faktor utama di dalam organisasi yang membuat karyawan puas terhadap pekerjaan yang dilakukan, dan kepuasan tersebut akan mendorong mereka untuk bekerja lebih baik, kedua faktor itu, antara lain :

1) Motivator, yaitu prestasi kerja, penghargaan, tanggung jawab yang diberikan, kesempatan untuk mengembangkan diri dan pekerjaanya itu sendiri.

2) Faktor kesehatan kerja, merupakan kebijakan administrasi perusahaan yang baik, supervise teknisi yang memadai, gaji yang memuaskan, kondisi kerja yang baik dan keselamatan kerja. Jenis motivasi ekstrinsik ini timbul sebagai akibat pengaruh dari luar individu, apakah karena adanya ajakan, suruhan atau paksaan dari orang lain sehingga dengan keadaan demikian seseorang mau melakukan sesuatu tindakan.

\section{Motivasi Ekstrinsik}

Menurut Herzberg (Hidayah et al, 2016: 3) motivasi ekstrinsik yang bersumber dari luar diri seseorang yang turut menentukan perilaku seseorang dalam kehidupan seseorang yang dikenal dengan hygiene factor. Adapun dimensi yang tergolong sebagai motivasi ekstrinsik sebagai berikut :

1) Kebijakan dan Administrasi : kebijakan dan administrasi yang menjadi motivasi ekstrinsik adalah kebijakan administrasi yang diterapkan oleh karyawan berkaitan dengan pekerjaan. Kebijakan dan administrasi umumnya dibuat dalam bentuk tertulis oleh pimpinan. Kebijakan atau administrasi yang dibuat dapat dijadikan pedoman bagi karyawan dalam melaksanakan pekerjaan sesuai dengan tugas dan tanggung jawab yang diberikan. Pelaksanaan kebijakan dan administrasi dilakukan masing-masing pimpinan yang bersangkutan supaya mereka dapat berbuat seadil-adilnya. 
2) Kualitas supervisi : kualitas pengawasan yang kurang baik dapat menimbulkan kekecewaan bagi karyawan. pimpinan harus paham cara mensupervisi karyawan sesuai dengan tanggung jawabnya. Pimpinan harus memiliki kecakapan untuk mengawasi karyawan dalam bekerja agar mereka merasa nyaman. Oleh karena itu, para pimpinan harus berusaha memperbaiki dirinya dengan jalan mengikuti pelatihan dan pendidikan.

3) Hubungan Antar Pribadi : Interpersonal relation menunjukan hubungan perseorangan antara bawahan dengan atasannya dan antara bawahan dengan rekan kerjanya, dimana kemungkinan bawahan merasa tidak dapat bergaul dengan atasannya atau rekan kerjanya

4) Kondisi Kerja : Masing-masing manajer dapat berperan dalam berbagai hal agar keadaan masingmasing bawahannya menjadi lebih sesuai. Misalnya ruangan khusus bagi unitnya, penerangan, perabotan suhu udara dan kondisi fisik lainnya. Kondisi lingkungan yang baik dapat tercipta, prestasi yang tinggi dapat dihasilkan melalui konsentrasi pada kebutuhan-kebutuhan ego dan perwujudan diri yang lebih tinggi.

5) Gaji : Pada umumnya masing-masing pimpinan tidak dapat menentukan sendiri skala gaji yang berlaku didalam unitnya. Namun demikian masingmasing manajer mempunyai kewajiban menilai apakah jabatanjabatan dibawah pengawasannya mendapat kompensasi sesuai pekerjaan yang mereka lakukan. Bagaimana jabatan didalam kantor diklarifikasikan dan elemen-elemen apa saja yang menentukan pengklasifikasikan itu.

\section{Loyalitas Karyawan}

Menurut Siagian (dalam Wellyanto dan Halim, 2017: 329) loyalitas merupakan suatu kecenderungan karyawan untuk tidak pindah ke perusahaan lain karena terdapat komitmen yang dimiliki untuk memberikan segala kemampuan, pikiran, dan keterampilan dalam mencapai tujuan perusahaan serta tetap setia pada perusahaan dengan menjaga segala rahasia perusahaan. Aspek-aspek loyalitas kerja yang menjadi dimensi dikemukakan oleh Siswanto (dalam Simbolon, 2015: 4) yang menitik beratkan pada pelaksanaan kerja yang dilakukan karyawan antara lain :

a. Taat pada peraturan : setiap kebijakan yang diterapkan dalam perusahaan untuk memperlancar dan mengatur jalannnya pelaksanaan tugas oleh manajemen perusahaan ditaati dan dilaksanakan denmgan baik.

b. Tanggung jawab pada perusahaan/organisasi : kesanggupan karyawan untuk melaksanakan tugas sebaik-baiknya dan tepat waktu serta kesadaran akan setiap resiko pelaksanaan tugasnya akan memberikan penjelasan tentang keberanian dan kesadaran bertanggung jawab terhadap resiko atas apa yang telah dilaksanakan

c. Kemauan untuk bekerja sama : bekerja sama dengan orang-orang dalam suatu kelompok akan memungkinkan perusahaan dapat mencapai tujuan yang tidak mungkin dicapai oleh orang-orang secara individual.

d. Rasa memiliki : Adanya rasa ikut memiliki karyawan terhadap perusahaan akan membuat karyawan memiliki sikap untuk ikut menjaga dan bertanggung terhadap perusahaan.

e. Hubungan antar pribadi : Karyawan yang mempunyai loyalitas kerja tinggi mereka akan mempunyai sikap fleksibel ke arah tata hubungan antara pribadi yaitu hubungan harmonis antara atasan dan bawahan.

f. Kesukaan terhadap pekerjaan : Perusahaan harus dapat menghadapi kenyataan bahwa karyawannya tiap hari datang untuk bekerjasama sebagai manusia seutuhnya dalam hal melakukan pekerjaan yang akan dilakukan dengan senang hati.

\section{Kerangka Pemikiran}

Berdasarkan teori diatas dapat dibuat kerangka pemikiran yang ditunjukan pada Gambar 1 sebagai berikut : 


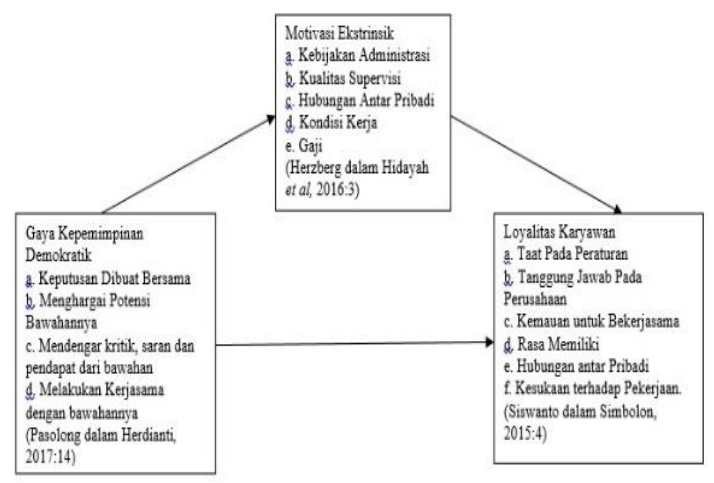

Sumber : olahan data peneliti (2019)

\section{Gambar 1 Kerangka Pemikiran}

\section{METODE PENELITIAN}

Penelitian ini menggunakan metode pendekatan kuantitatif. Jenis penelitian ini adalah deskriptif dan kausal. Lokasi penelitian yaitu PT Propan Raya ICC Bandung. Skala pengukuran dengan menggunakan skala likert. Populasi reponden adalah karyawan tetap. Teknik sampel yang digunakan yaitu sampel jenuh. Pada penelitian ini sampel yang digunakan yaitu seluruh populasi yaitu seluruh karyawan tetap berjumlah 42. Teknik pengumpulan data melalui data primer dan data sekunder. Teknik analisis data pada penelitian ini yaitu analisis deskriptif, Method of successive interval (MSI), Uji asumsi klasik dan Path Analysis. Penelitian ini dilakukan selama 4 bulan terhitung bulan November, Desember, Januari dan Februari. Variabel operasional yang digunakan yaitu variabel independent gaya kepemimpinan demokratik, variabel dependent loyalitas karyawan dan variabel intervening motivasi ekstrinsik.

\section{PEMBAHASAN}

Berdasarkan penelitian yang dilakukan terhadap 42 responden sebagai sampel dengan karakteristik mayoritas laki-laki 32 karyawan $(76,19 \%)$, mayoritas memiliki tingkat pendidikan terakhir S1 yaitu sebanyak 16 karyawan $(38,10 \%)$. mayoritas bekerja selama $>10$ tahun sebanyak 21 karyawan (50\%), dan mayoritas berusia antara 36-45 tahun sebanyak 17 karyawan $(40,48 \%)$.

\section{Analisis Deskriptif Variabel Gaya Kepemimpinan Demokratik \\ Berdasarkan hasil analisis deskriptif gaya} kepemimpinan demokratik di PT Propan Raya ICC Bandung mendapat nilai persentase sebesar $75,23 \%$, nilai ini termasuk dalam kategori baik yang artinya responden merasa bahwa gaya kepemimpinan demokratik yang dilakukan telah berjalan dengan baik. Dari 10 pernyataan skor yang memiliki nilai tertinggi yaitu dimensi melakukan kerjasama dengan bawahan pada item "pimpinan mampu untuk bekerja sama dengan bawahan" memperoleh nilai sebesar $83,80 \%$.. Namun pada dimensi mendengar kritik, saran dan pendapat dari bawahan dengan item "pimpinan mendengar pendapat dari bawahan" memperoleh nilai terendah sebesar 70,47\%, namun masih dalam kategori baik. hal ini bisa disebabkan karna pemimpin terlalu fokus untuk mengejar pencapaian target sales sehingga kurangnya mendengar pendapat dari bawahan.

\section{Analisis Deskriptif Variabel Loyalitas Karyawan}

Berdasarkan hasil analisis deskriptif loyalitas karyawan di PT Propan Raya ICC Bandung mendapat skor sebesar 78,20\% tersebut termasuk dalam kategori baik yang artinya responden merasa bahwa loyalitas karyawan yang ada di PT Propan Raya ICC telah berjalan dengan baik. Dari 13 pernyataan skor yang memiliki nilai tertinggi yaitu dimensi hubungan antar pribadi pada item "Saya selalu memberikan dorongan yg positif terhadap rekan kerja" memperoleh nilai sebesar 85,71\%. Namun pada dimensi tanggung jawab pada perusahaan item "Saya bertanggung jawab terhadap setiap konsekuensi yg dibebankan kepada saya" memperoleh nilai terendah sebesar $71,90 \%$, namun masih dalam kategori baik. Hal ini disebabkan karena rata-rata pekerjaan di PT Propan Raya ICC Bandung dari setiap karyawan memiliki target 
pencapaian dalam tim namun setiap karyawan juga memiliki target pencapaian secara individu yang harus dicapai sehingga karyawan masih belum bisa menerima konsekuensi yang dibebankan atas pekerjaan tersebut.

\section{Analisis Deskriptif Variabel Motivasi Ekstrinsik}

Berdasarkan hasil analisis deskriptif motivasi ekstrinsik di PT Propan Raya ICC Bandung mendapat skor sebesar $75,71 \%$ tersebut termasuk dalam kategori baik yang artinya responden merasa bahwa motivasi ekstrinsik yang ada di PT Propan Raya ICC telah berjalan dengan baik. Dari 12 pernyataan skor yang memiliki nilai tertinggi yaitu dimensi kualitas supervisi pada item "cara pengawasan yang dilakukan pimpinan membuat saya semangat dalam bekerja" memperoleh nilai sebesar $85,71 \%$. hal ini menunjukan bahwa pimpinan memiliki pengawasan yang baik dalam bekerja - Namun pada dimensi kualitas supervisi dengan item "pimpinan berperilaku adil kepada semua karyawan" memperoleh nilai terendah sebesar 66,19\%, namun masih di kategorikan baik . hal ini dikarenakan adanya kecemburuan sosial terhadap satu karyawan terhadap karyawan lain yang merasa karyawan tersebut lebih diutamakan.

\section{Pengaruh Gaya Kepemimpinan Demokratik Terhadap Motivasi Ekstrinsik Hasil penelitian nilai koefisien regresi untuk pengaruh gaya kepemimpinan demokratik terhadap motivasi ekstrinsik adalah 0,872 dan tingkat signifikansi sebesar $0,000<0,05$ sehingga dapat diartikan bahwa gaya kepemimpinan demokratik berkontribusi secara signifikan terhadap motivasi ekstrinsik. Besarnya pengaruh gaya kepemimpinan demokratik yang secara langsung mempengaruhi motivasi ekstrinsik adalah $0,872^{2}=0,760$ atau $76 \%$. Dengan peningkatan gaya kepemimpinan demokratik maka dapat meningkatkan motivasi ekstrinsik sebesar $76 \%$.}

Pengaruh Gaya Kepemimpinan Demokratik Terhadap Loyalitas Karyawan Hasil penelitian nilai koefisien regresi untuk pengaruh gaya kepemimpinan demokratik terhadap loyalitas karyawan adalah 0,660 dan signifikansi $0,000<0,05$ sehingga dapat diartikan gaya kepemimpinan demokratik berkontribusi secara signifikan terhadap loyalitas karyawan. Besarnya pengaruh gaya kepemimpinan demokratik yang secara langsung mempengaruhi loyalitas karyawan adalah $0,660^{2}=0,4356$ atau $43,56 \%$. Dengan peningkatan gaya kepemimpinan demokratik maka dapat meningkatkan loyalitas karyawan sebesar $43,56 \%$.

\section{Pengaruh Gaya Kepemimpinan Demokratik Terhadap Loyalitas Karyawan melalui Motivasi Ekstrinsik}

Hasil penelitian yang terdapat dari hasil $\mathrm{R}^{2}$ terdapat besarnya pengaruh variabel gaya kepemimpinan demokratik terhadap loyalitas karyawan melalui motivasi ekstrinsik sebesar 0,883 dan signifikansi $0,000<0,05$. Selanjutnya untuk mengetahui pengaruh tidak langsung diperoleh dari nilai koefisien jalur gaya kepemimpinan demokratik terhadap motivasi ekstrinsik (XZ) dikalikan dengan nilai koefisien jalur motivasi ekstrinsik terhadap loyalitas karyawan (ZY) menjadi $(0,872 \mathrm{x}$ $0,307)=0,267$. Hasil perkalian menunjukan bahwa nilai koefisien berpengaruh tidak langsung (XZ $\mathrm{x} \quad \mathrm{ZY})$ lebih kecil jika dibandingkan nilai koefisien pengaruh langsung (XY) yaitu 0,660>0,267 . Dengan demikian total pengaruh gaya kepemimpinan terhadap loyalitas melalui motivasi ekstrinsik sebesar 0,267.

Hasil pengolahan dan analisis data telah menunjukkan bahwa gaya kepemimpinan demokratis memberikan kontribusi terhadap loyalitas karyawan melalui motivasi ekstrinsik sebesar $88,3 \%$ sedangkan sisanya sebesar $11,7 \%$ dipengaruhi oleh faktor lain. Hasil penelitian ini relevan seperti penelitian terdahulu (Marfuah dan Ruzikna, 2015) bahwa gaya kepemimpinan demokratis berpengaruh signikan terhadap loyalitas karyawan dengan diperoleh nilai $\mathrm{r}$ (koefisien Korelasi) sebesar $0.543 \%$ artinya $54,3 \%$ dan sisanya $45,7 \%$ dipengaruhi faktor lain, dan hasil penelitian dari (Kusuma, 2017) dalam penelitian yang dilakukan membuktikan bahwa motivasi ekstrinsik berpengaruh secara signifikan terhadap loyalitas karyawan. 


\section{PENUTUP}

Berdasarkan hasil penelitian dan pembahasan mengenai gaya kepemimpinan demokratik terhadap loyalitas karyawan melalui motivasi ekstrinsik sebagai variabel intervening di PT Propan Raya ICC Bandung", dapat disimpulkan bahwa Gaya Kepemimpinan Demokratik yang dilakukan dilingkungan PT Propan Raya ICC Bandung sudah termasuk pada kategori baik, Loyalitas Karyawan yang dilakukan dilingkungan PT Propan Raya ICC Bandung sudah termasuk pada kategori baik, Motivasi Ekstrinsik yang dilakukan dilingkungan PT Propan Raya ICC Bandung sudah termasuk pada kategori baik, Gaya Kepemimpinan Demokratik berpengaruh secara signifikan terhadap Motivasi Ekstrinsik di PT Propan Raya ICC Bandung, Gaya Kepemimpinan Demokratik berpengaruh secara signifikan terhadap Loyalitas Karyawan di PT Propan Raya ICC Bandung dan Gaya Kepemimpinan Demokratik berpengaruh secara signifikan terhadap Loyalitas Karyawan melalui Motivasi Ekstrinsik di PT Propan Raya ICC Bandung.

Saran untuk penelitian selanjutnya peneliti dapat melakukan penelitian pada perusahaan sejenis dengan variabel penelitian yang sama namun ditambah dengan faktor motivasi intrinsik, sehingga hasilnya dapat dijadikan sebagai bahan perbandingan. Melakukan penelitian terhadap faktor-faktor diluar faktor yang diteliti oleh peneliti yang mempengaruhi loyalitas, seperti pelatihan, kompensasi, lingkungan kerja dan pengembangan karir serta diharapkan pada penelitian selanjutnya dapat memperbanyak jumlah sampel penelitian.

\section{REFERENSI}

Afani, Tri. (2013). Analisis Pengaruh Gaya Kepemimpinan Terhadap Loyalitas Pegawai pada Badan Kepegawaian. Skripsi pada Institut Pertanian Bogor.
Anasrulloh, Muhammad., dan Agatha, Maria.W. Pengaruh Gaya Kepemimpinan dan Motivasi terhadap Loyalitas Karyawan (Studi Kasus pada Pondok Usaha Aba Tulungagung). Jurnal. UNPGRI Kediri.

http://ojs.unpkediri.ac.id/index.php/ manajemen/article/view/12566.

Frianto, Agus., \& Putra, A.K. (2013 ). Pengaruh motivasi intrinsic dan motivasi ekstrinsik terhadap kepuasan kerja. Jurnal Ilmu Manajemen. Jurusan Manajemen Fakultas Ekonomi Universitas Negeri Surabaya. Vol 1 No 1, 377387. https://jurnalmahasiswa.unesa.ac.id/i ndex.php/jim/article/view/2140.

Hidayah, B.S., Saleh, C., \& Prihantini, D. (2016). Pengaruh Motivasi Intrinsik dan Motivasi Ekstrinsik terhadap Kinerja melalui Perilaku Kerja Karyawan Honorer Hotel dan Pemandian Kebonagung Jember. Jurnal Manajemen. Universitas Jember. http://repository.unej.ac.id/handle/12 $\underline{3456789 / 77656 .}$

Kusuma, Intan. (2017). Pengaruh Motivasi Ekstrinsik terhadap Loyalitas Karyawan PT Industri Lift Indo Nusantara. Skripsi Thesis. Universitas Airlangga.

Ruzikna. \& Marfuah. (2015 ). Pengaruh gaya demokratis terhadap loyalitas karyawan (studi kasus Hotel Olgaria Pekanbaru). Jurnal Administrasi Bisnis. Jurusan Administrasi Bisnis Fakultas Ilmu politik. Universitas Riau. Vol 2 No 2, 1-15. https://jom.unri.ac.id/index.php/JO 
MFSIP/article/view/7355.

Simbolon, Hotma B.R. (2015). Pengaruh Motivasi Terhadap Loyalitas Kerja Karyawan Bagian Marketing pada PT.Agung Automall Cabang Pekanbaru. Jurnal. Jurusan Adiminstrasi Bisnis Universitas Riau No. 2 Vol. 1 . https://jom.unri.ac.id/index.php/JO MFSIP/article/view/5105.

Sugiyono. (2013). Metode Penelitian Kualitatif dan Kuantitatif dan $R \& D$. Bandung: Alfabeta.

Sugiyono. (2017). Metode Penelitian Kuantitatif, Kualitatif, dan $R \& D$. Bandung: Alfabeta.

Sunyoto, Danang. (2015). Manajemen dan Pengembangan Sumber Daya Manusia (Cetakan Pertama). Yogyakarta: CAPS (Center for Academic Publishing Service).

Soegandhi, Vannecia. M dkk. (2013). Pengaruh Kepuasan Kerja dan Loyalitas Kerja Terhadap Organizational Citizenship Behavior Pada Karyawan PT Surya Timur Sakti Jatim. Jurnal. Program Manajemen Bisnis, Program Studi Manajemen. Universitas Kristen Petra. Vol 1. No 1. http://repository.petra.ac.id/16255/.

Thoha, Miftah. (2013). Kepemimpinan dalam manajemen. Edisi 1. Jakarta: PT Grafindo.

Wellyanto, S.C. \& Halim, A.G. (2017). Analisa pengaruh gaya kepemimpinan terhadap loyalitas karyawan Hotel $x$ di Bali. Jurnal Manajemen Perhotelan, Fakultas Ekonomi. Universitas Kristen Petra Surabaya.

http://publication.petra.ac.id/index.p

$\mathrm{hp} /$ manajemen-

perhotelan/article/view/5963.

\section{BIODATA PENULIS}

Vinny Hafisah. Lahir di Bandung, 5 juni 1996 dan menyelesaikan pendidikan S1 di Universitas Telkom Bandung Jurusan Ilmu Administrasi Bisnis pada tahun 2019. 